\title{
Standing: Taxpayers and Others
}

\author{
Kenneth Culp Davis
}

The Supreme Court held in Flast $v$. Cohen ${ }^{1}$ that taxpayers have standing to challenge the constitutionality of federal expenditures under "specific" clauses of the Constitution. To the extent that the law of the Frothingham case of $1923^{2}$ was to the contrary, it is overridden. The narrow holding seems impregnable and seems destined to become a long-term cornerstone of the law of standing.

Yet the Court's analysis creates new uncertainties and new problems, which are the occasion for this commentary. The uncertainties and problems stem largely from the Court's conclusion that taxpayers lack standing to challenge expenditures under non-specific clauses of the Constitution, and from its failure to consider the taxpayers' standing to challenge the statutory authority of the disbursing officers, even though that question was clearly raised.

The questions opened up by the Flast opinion reach into vital areas of our constitutional system, of the role of the judiciary in review of legislation, and of judicial review of administrative action. The questions are highly practical and immediate, and yet they are in some ways fundamental.

\section{The FLAST Holding}

The suit was brought by seven plaintiffs who pay income taxes, who, the Court said, "were resting their standing to maintain the action solely on their status as federal taxpayers."3 The defendants were the Secretary of Health, Education, and Welfare and the Commissioner of Education "in their official capacities." The complaint was quite clear in raising nonconstitutional issues as well as constitutional ones; it prayed for a declaratory judgment that the action of the defendants in approving federal expenditures was

Kenneth Culp Davis is John P. Wilson Professor of Law, The University of Chicago. The author expresses his appreciation to his wise colleague, Professor Philip B. Kurland, for advising and abetting.

188 S. Ct. 1942 (1968).

2 Frothingham v. Mellon, 262 U.S. 447 (1923).

388 S. Ct. at 1945. 
not authorized or intended by the Elementary and Secondary Education Act of 1965, or in the alternative if such determination and action are within the authority and intent of the Act, the Act is to that extent unconstitutional and void. ${ }^{4}$

The complaint also prayed for an injunction against expenditure of federal funds for religious schools. The substantive allegation was that federal funds were being used to finance instruction and materials in reading, arithmetic, and other subjects in religious schools, in contravention of the establishment and free exercise clauses of the first amendment.

A three-judge court was convened, which, by a vote of two to one, dismissed the complaint for lack of standing, ${ }^{5}$ the majority resting its decision on the authority of the Frothingham case. The taxpayers took a direct appeal to the Supreme Court.

The Supreme Court first rejected the government's challenge of its jurisdiction on the ground that a three-judge court had been improperly convened. The Court granted that the complaint "states a nonconstitutional ground for relief, namely, that appellees' actions in approving the expenditure of federal funds for allegedly unconstitutional programs [are] in excess of their authority under the Act,"6 but it said that the constitutional ground for relief was enough to justify the threejudge court.

In the first paragraph of the opinion, the Court said:

In this case, we must decide whether the Frothingham barrier should be lowered when a taxpayer attacks a federal statute on the ground that it violates the Establishment and Free Exercise Clauses of the First Amendment. ${ }^{7}$

That sentence ignored the "nonconstitutional ground for relief." So did the entire opinion, with the exception of the discussion of the question whether the three-judge court should have been convened.

Even though the constitutional challenge was under both the free exercise clause and the establishment clause of the first amendment, the Court declared that the establishment clause "specifically" limits the taxing and spending power, and that

whenever such specific limitations are found, we believe a taxpayer will have a clear stake as a taxpayer in assuring that they are not breached by Congress. Consequently, we hold that a

4 Id., Record at 10a.

5 Flast v. Gardner, 271 F. Supp. I (S.D.N.Y. 1967).

688 S. Ct. at 1947.

7 Id. at $1944-45$. 
taxpayer will have standing consistent with Article III to invoke federal judicial power when he alleges that congressional action under the taxing and spending clause is in derogation of those constitutional provisions which operate to restrict the exercise of the taxing and spending power. The taxpayer's allegation in such cases would be that his tax money is being extracted and spent in violation of specific constitutional protections against such abuses of legislative power. Such an injury is appropriate for judicial redress, and the taxpayer has established the necessary nexus between his status and the nature of the allegedly unconstitutional action to support his claim of standing to secure judicial review. ${ }^{8}$

So the holding was that taxpayers have standing to raise issues about constitutionality of federal disbursements under "specific" clauses of the Constitution and that the establishment clause is a "specific" clause. ${ }^{9}$

\section{Standing To Raise Nonconstitutional Issues}

Over the long term, I think taxpayer standing to challenge federal expenditures on the ground of lack of statutory authority may be more important than such standing to challenge on the ground of lack of constitutional power, especially since the process of giving meaning to unclear statutes in order to render them constitutional is deemed statutory interpretation. The Flast complaint prayed for a declaration that the officers' action was "not authorized or intended" by the statute, and, if it was authorized, that the statute be declared to that extent unconstitutional. The reply brief for appellants (plaintiffs) accurately said at page 2:

It has been our position throughout the proceedings that the programs challenged are not authorized by the statute and that, if they are, the statute is unconstitutional.

Yet the Supreme Court's entire discussion of standing was limited to standing to raise constitutional issues, and the Court said nothing about standing to raise nonconstitutional issues.

Why the Court did not consider standing to raise nonconstitutional

8 Id. at 1955.

9 Three Justices wrote concurring opinions and one wrote a dissenting opinion. The Douglas opinion would "be rid of Frothingham here and now." Id. at 1956. The Stewart opinion interpreted the majority to mean that a taxpayer may challenge under the establishment clause, and the Fortas opinion would confine the ruling to the proposition that a taxpayer may challenge under the establishment clause. The Harlan dissent is analyzed in section vr of this article. 
issues does not appear. The reason may conceivably be some subtle consideration of substance or strategy that I cannot fathom. Or it may be the psychological dominance of the Frothingham doctrine and the question whether that prominent doctrine should be cut into; the glamor of that issue may have seemed so dazzling that mere nonconstitutional issues were too dark to detect. Or it may have been the parties' focus on the constitutional issues in their briefs. Or it may have been mere forgetfulness or inadvertence.

The Court's failure to consider the question of standing to raise issues about the statutory authority of the officers may have had a crucial negative effect upon the Court's conclusion that "a taxpayer will have a clear stake as a taxpayer" in raising some constitutional issues and not others. Could the Court have said also that a taxpayer "as a taxpayer" has standing to raise some questions of officers' statutory authority but not other questions of such statutory authority? I doubt it. After all, a taxpayer who is financially affected by disbursements which exceed an officer's statutory authority in one respect is equally affected financially if the disbursements exceed the statutory authority in another respect. If the Court had had to think through the question whether a taxpayer had standing to raise some questions of statutory authority and not others, perhaps it would have rejected the idea that a taxpayer has standing to raise some constitutional issues and not others.

Both logic and practicality seem to me to require this proposition: A person who has standing to challenge for one kind of illegality that adversely affects him necessarily has standing to challenge for another kind of illegality that adversely affects him to the same extent. Any judge-made law that departs from this logical and practical proposition, in my opinion, cannot long endure, whether it relates to constitutional issues or to statutory authority.

\section{The Court's Reasons for Concluding that a Taxpayer has No Standing To Ghallenge UNDER a NON-Specific Clause}

In holding that taxpayers have standing to challenge disbursements under the establishment clause, the Supreme Court drew a distinction between "specific limitations" and other constitutional limitations and concluded that taxpayers have no standing to challenge disbursements under non-specific clauses. I think the reasons the Court gave for lack of taxpayer standing to challenge under non-specific clauses will not stand analysis.

The Court began by asserting an unreasoned conclusion that a tax- 
payer may challenge an exercise of the congressional power to tax and spend but may not challenge incidental expenditures in administering "an essentially regulatory statute." This assertion can become law by reason of the Court's fiat, but it seems illogical, because all government spending is probably an exercise of the congressional power to tax and spend even when it is also within the power to regulate interstate commerce. The Court then asserted that

the taxpayer must show that the challenged enactment exceeds specific constitutional limitations imposed upon the exercise of the congressional taxing and spending power and not simply that the enactment is generally beyond the powers delegated to Congress by Art. I, $\S 8 .^{10}$

The Court did not explain why it deemed the first amendment more specific than the tenth amendment. I agree that the first amendment imposes specific constitutional limitations, and I agree that an argument that an enactment is generally beyond congressional powers is less specific, but in absence of some explanation of what the Court had in mind, I cannot see wherein the first amendment is more "specific" than the tenth amendment. Perhaps the Court did not at this point have in mind the tenth amendment.

But more important is the Court's explanation of why a taxpayer has standing to challenge under a "specific" clause but not under a nonspecific clause. The Court said that when the injury is from "violation of specific constitutional protections" it is "appropriate for judicial redress" and that

Under such circumstances, we feel confident that the questions will be framed with the necessary specificity, that the issues will be contested with the necessary adverseness and that the litigation will be pursued with the necessary vigor to assure that the constitutional challenge will be made in a form traditionally thought to be capable of judicial resolution. We lack that confidence in cases such as Frothingham where a taxpayer seeks to employ a federal court as a forum in which to air his generalized grievances about the conduct of government or the allocation of power in the Federal System. ${ }^{11}$

The two sentences just quoted contain the only reasons the Court advances for its conclusion that a taxpayer has no standing to challenge a disbursement under a non-specific clause of the Constitution. My

$1088 \mathrm{~S}$. Ct. at 1954 .

11 Id. at $1955-56$. 
opinion is that these two sentences are unconvincing and that they are an unsatisfactory basis for deciding whether a taxpayer has standing to challenge a disbursement. The Court's three items-specificity, adverseness, and vigor-are unquestionably desirable from a court's standpoint in any litigation, but I think the three items may be either present or absent when a taxpayer makes his challenge under a "specific" clause and that they may be either present or absent when a taxpayer makes his challenge under a non-specific clause. I think the three items depend almost wholly upon the skill of counsel or lack of it and not at all upon the degree of specificity of the constitutional clause under which the challenge is made.

Furthermore, the Court's reasons seem to me unsatisfactory because the Court does not even attempt to explain why a taxpayer has standing to make a challenge under the establishment clause even when the three items are absent, or why a taxpayer lacks standing to make a challenge under the tenth amendment even when the three items are present.

The Court's only additional reason for singling out "specific" clauses for taxpayer enforcement is an elaboration of its statement that

Our history vividly illustrates that one of the specific evils feared by those who drafted the Establishment Clause and fought for its adoption was that the taxing and spending power would be used to favor one religion over another or to support religion in general. ${ }^{12}$

The Court's historical proposition seems unquestionably true, but does not our history also vividly illustrate that those who drafted the tenth amendment and fought for its adoption had an intent that it should not be violated, just as they intended that the establishment clause not be violated?

The Flast taxpayers argued at page 37 of their main brief that they were suing

to prevent a pocketbook injury but only because that is part of what they deem a much graver injury, an injury to the right to live under a government which separates itself strictly from the church and church affairs.

Suppose a taxpayer who has an obsession against a strong central government challenges a spending program on the ground that it exceeds the powers of Congress and therefore violates the tenth amendment, and he argues that he sues to prevent a pocketbook injury but only because that is a part of what he deems a much graver injury, an injury

12 Id. at 1954. 
to the right to live under a government in which the Congress refrains from exercising powers not delegated to it by the Constitution. Does this argument have any less merit than the parallel argument made by the Flast taxpayers? I think the two arguments are of equal merit as they affect the standing problem. ${ }^{13}$

Another major item in the opinion seems to me unsound and worthy of comment even though in this case a correction of it would have made no difference in the Court's conclusions. The Court asserted that the words "cases" and "controversies" of article III "limit the business of federal courts to questions presented in an adversary context." 14 This, I think, simply is not so, and it never has been. From the beginning, federal courts have performed many functions in addition to deciding "questions presented in an adversary context." Federal courts often decide questions of law and fact and discretion in absence of an adversary context, as they do when they issue consent decrees to parties who are in complete agreement, accept pleas of guilty and impose sentences that are not opposed, enforce subpenas that are not resisted, dispose of voluntary petitions in bankruptcy when all parties affected are in agreement, probate decedents' estates in the District of Columbia and in the territories when all parties are in agreement, admit aliens to citizenship when no issue arises, and enjoin strikes for eighty days when parties on both sides join in asking for the injunction. Earlier in the opinion the Court properly said that standing involves constitutional considerations and policy considerations, and later it said that

in terms of Article III limitations on federal court jurisdiction, the question of standing is related only to whether the dispute sought to be adjudicated will be presented in an adversary context and in a form historically viewed as capable of judicial resolution. ${ }^{15}$

A sound formulation, in my opinion, would be that article III requires that a case be "capable of judicial resolution" and that long-standing

13 Substantively, the tenth amendment argument seems almost sure to fail. But that is also true of the substantive position of the Flast taxpayers, as shown by Board of Educ. v. Allen, 88 S. Ct. 1923 (1968), decided the same day as the Flast case.

Indeed, the substantive argument that Congress lacks power to tax and spend for the general welfare is so weak that the Court would have done better in the Flast opinion to have refrained from trying to cut off taxpayer challenges of spending programs under the tenth amendment; a sounder way to get rid of such taxpayer challenges would be through a clear holding that art. I, § 8 means that Congress may tax and spend for the general welfare.

$1488 \mathrm{~S}$. Ct. at 1950.

15 Id. at 1953. 
judicial policy requires "an adversary context" for a private party to challenge governmental action. ${ }^{\mathbf{1 6}}$

The Court in the Flast opinion relied upon its remark in Baker $v$. Carr that "the gist of the question of standing" is whether the plaintiff has alleged

such a personal stake in the outcome of the controversy as to assure that concrete adverseness which sharpens the presentation of issues upon which the court so largely depends for illumination of difficult constitutional questions. ${ }^{17}$

As a statement of judicial policy, this remark is a helpful one and a good foundation on which to build the law of standing, except that the Court should not imply that "the question of standing" is limited to "constitutional" questions, and except that even a large personal stake in the outcome cannot "assure" the desired sharpening.

\section{May a Taxpayer Have a Stake "As a Taxpayer" in a Violation of One Gonstitutional Glause But Not in a VIOLATION OF ANOTHER?}

How can a taxpayer "as a taxpayer" have a stake in a violation of the establishment clause but not in a violation of a non-specific clause of the Constitution?

One approach to such a problem about standing is the conventional approach, which has been codified by the Administrative Procedure Act. Section 702 governs standing:

A person suffering legal wrong because of agency action, or adversely affected or aggrieved by agency action within the meaning of a relevant statute, is entitled to judicial review thereof. ${ }^{18}$

Quite independently, section 706 provides:

The reviewing court shall ... set aside agency action ... found to be ... contrary to constitutional right ... [or] in excess of statutory authority.

This quite clearly means that one who has standing is entitled to raise any question of "constitutional right," not just those involving violations of "specific limitations," and any question of statutory authority.

16 When action a federal court is contemplating on the basis of consent of all parties appears to the court to involve a constitutional question, the court is clearly obligated to decide the constitutional question despite the absence of an adversary context.

17369 U.S. 186, 204 (1962).

185 U.S.C. \& 702 (Supp. II, 1967). 
Mr. Justice Harlan was using this conventional approach when he said in his dissenting opinion:

I am quite unable to understand how, if a taxpayer believes that a given public expenditure is unconstitutional, and if he seeks to vindicate that belief in a federal court, his interest in the suit can be said necessarily to vary according to the constitutional provision under which he states his claim. ${ }^{19}$

The Harlan statement may reach a generally sound conclusion, but I think that the problem may be somewhat more complex than the simple statement indicates. A taxpayer's interest, I think, may "vary according to the constitutional provision under which he states his claim." One taxpayer may have a religious interest in objecting to use of his tax money for religion, another taxpayer may have a non-religious interest in objecting to some other violation, and the interests of the two taxpayers may differ in the degree of support they give to the taxpayers' standing, so that one may suffice and the other may not.

But even if the interests of two taxpayers may vary according to the constitutional provisions they invoke, every taxpayer may have a sufficient financial interest in an unlawful disbursement to satisfy the requirements for standing, so that an additional interest, such as a religious interest, will have no effect on the question of standing. To determine whether this is so, we must ask: What was the specific interest of the taxpayers that the Court found sufficient for standing in the Flast case?

The Court gave no clear answer. It said that the establishment clause "does specifically limit the taxing and spending power," and that "whenever such specific limitations are found, we believe a taxpayer will have a clear stake as a taxpayer in assuring that they are not breached by Congress."'20 And it said that the taxpayer's allegation was

that his tax money is being extracted and spent in violation of specific constitutional protections against such abuses of legislative power. Such an injury is appropriate for judicial redress.... ${ }^{21}$

The Court did not say whether the "injury" was economic or religious or both. Which was it?

Plausible arguments can be made that it was religious, that it was economic, and that it was both. The Court's assertion in Flast that a

$1988 \mathrm{~S}$. Ct. at 1965.

20 Id. at 1955.

21 Id. 
taxpayer has "a clear stake as a taxpayer" might at first seem to pull toward the view that the "injury" was economic, because an individual who has an interest in religion does not have it "as a taxpayer," but that first impression has to yield to the idea that a taxpayer "as a taxpayer" may have a religious interest in freedom from compulsory taxation to support religion; after all, one historical facet of free religion is freedom from being compelled to support religion through paying taxes. Of course, the argument that the "injury" is economic is that the taxpayer has a proportionate interest in each public expenditure and he is hurt when an expenditure is unlawfully made. The "injury" can obviously be a combination of the religious and the economic, and that might be the best conclusion-except for two further factors.

The two further factors are that (1) the Supreme Court has already taken a clear position on the question, which is binding in absence of sufficient reason to depart from it, and that (2) the plaintiffs in the Flast complaint made no allegations disclosing their religious interests or asserting any injury to them.

That the Court's position was taken in a context of state and local rather than federal taxation does not matter, for the principle is the same. The two cases of Everson ${ }^{22}$ and Doremus, ${ }^{23}$ taken together, seem to yield a clear answer. In Everson, the Court considered on the merits a taxpayer's challenge of New Jersey's reimbursement to parents of money they spent for transporting their children to public schools and to Catholic parochial schools. In Doremus, taxpayers sought to challenge Bible reading in New Jersey schools, and the Court held that they lacked standing. The difference, according to the Doremus opinion, was that

because our own jurisdiction is cast in terms of "case or controversy," we cannot accept as the basis for review, nor as the basis for conclusive disposition of an issue of federal law without review, any procedure which does not constitute such.

The taxpayer's action can meet this test, but only when it is a good-faith pocketbook action. It is apparent that the grievance which it is sought to litigate here is not a direct dollars-and-cents injury but is a religious difference. If appellants established the requisite special injury necessary to a taxpayer's case or controversy, it would not matter that their dominant inducement to action was more religious than mercenary. It is not a question of motivation but of possession of

22 Everson v. Board of Educ., 330 U.S. 1 (1947).

23 Doremus v. Board of Educ., 342 U.S. 429 (1952). 
the requisite financial interest that is, or is threatened to be, injured by the unconstitutional conduct. ${ }^{24}$

So a state taxpayer, according to the Supreme Court in Everson and Doremus, has standing to challenge a spending program but not a Bible-reading program not involving spending. The test is whether the taxpayer's action is "a good-faith pocketbook action," and the test is met when the challenge goes to spending, for then the taxpayer sustains "a direct dollars-and-cents injury." The test was clearly satisfied by the Flast complaint. The conclusion seems rather clear, on the authority of Everson and Doremus, that the Flast taxpayers were "adversely affected" financially by the challenged disbursements.

Furthermore, because the Flast taxpayers made no allegation that they had any religious interests or that their religious interests were in any way injured, their standing could hardly be based on injury to their religious interests.

\section{To Suffice for Standing, Must an Interest Be Substantial or May It Be Trifling?}

Quite significant is the Supreme Court's lack of inquiry into the extent of the taxpayers' interests in Everson and Flast, where taxpayers were held to have standing. Yet the Supreme Court said later that Everson had suffered "a direct dollars-and-cents injury." 25 The injury may have been trifling, but figures are unavailable to estimate it. In Flast, the record furnishes no basis for an estimate. But out of curiosity I have made a calculation based on if's: If a billion dollars are spent on the national education program, if New York City's share is fifty million, and if a quarter of that goes to parochial schools, their portion is twelve and one-half million, which is one eight-thousandth of a federal budget of a hundred billion, so that one who pays federal taxes of a thousand dollars is hurt about twelve cents by the alleged illegality of the New York City program.

Should a stake of some such sum as twelve cents be enough for standing? One answer comes from James Madison, whose "three pence" are only a little more than twelve cents after adjusting for inflation:

The same authority which can force a citizen to contribute three pence only of his property for the support of any one 
establishment, may force him to conform to any other establishment in all cases whatsoever. ${ }^{26}$

When important principle is the real stake, Madison would probably undergo huge litigation costs to fight for three pence. Why not allow a modern Madison to do so?

At this point, we must carefully distinguish between a plaintiff's motivation and the interest that may suffice for his standing. The motivation of Everson was undoubtedly religious, but the basis for his standing was "a direct dollars-and-cents injury." The motivation of each plaintiff in the Flast case was undoubtedly religious, but I think the basis for standing was probably financial, even if it was as small as twelve cents. Quite important is the Court's Doremus statement:

It is not a question of motivation but of possession of the requisite financial interest that is, or is threatened to be, injured by the unconstitutional conduct. ${ }^{27}$

Injuries that suffice for standing are often trivial-much smaller than litigation costs even in a lower court. For instance, in McGowan v. Maryland, each private party's formal stake was a fine of "five dollars and costs." 28 In Baker v. Carr, ${ }^{29}$ as well as in nearly all the reapportionment cases, the formal stake the Court held enough for standing was a fraction of one vote. In Harper, the formal stake was a poll tax of $\$ 1.50$ imposed on each plaintiff. ${ }^{30}$ In the School Prayer Case, the children had a choice between being present during recitation of a prayer that offended their religion and taking the initiative to absent themselves while the prayer was recited; the injury was held to suffice for standing. ${ }^{31}$ Even one who can without perjury take a loyalty oath has standing to challenge the unconstitutionality of requiring the oath because of "the risk of unfair prosecution and the potential deterrence of constitutionally protected conduct." 32 A taxpayer has standing to challenge exemption of other taxpayers, presumably because of denial of equality, even though he cannot show that his tax will be affected if the others pay; how large is that injury? ${ }^{33}$

26 Quoted by Black, J., in International Ass'n of Machinists v. Street, 367 U.S. 740, 790 (1961).

27342 U.S. at 435.

28366 U.S. 420 (1961).

29369 U.S. 186 (1962). The Court said at 207: "The injury . . . is that this classification disfavors the voters in the counties in which they reside...."

30 Harper v. Virginia Board of Elections, 383 U.S. 663 (1966).

31 Engel v. Vitale, 370 U.S. 421 (1962).

32 Cramp v. Board of Public Instruction, 368 U.S. 278, 283 (1961).

33 Allied Stores v. Bowers, 358 U.S. 522 (1959). The unequal treatment seems to be a clear injury even if the measure of it is something like zero. 
The basic idea that comes out in numerous cases is that an identifable trifle is enough for standing to fight out a question of principle; the trifle is the basis for standing and the principle supplies the motivation. Just as Madison thought that an expenditure of three pence was enough to show unconstitutionality, a typical plaintiff thinks that a tiny immediate interest is enough to raise a large question of principle. Probably this characteristic attitude of the human being who litigates is a sound foundation on which to build the law of standing.

Common law that has endured for centuries is based on the human nature that impels assertion of principle when only a trifle is immediately involved. If A steps on B's land, touches B's person, or points a gun at $\mathrm{B}$, in each instance causing damage or injury so trifling that it is not discernible, $B$ nevertheless has a cause of action for trespass, for battery, or for assault. The common law in each instance allows the plaintiff, on the basis of the trifle, to assert principle.

Just as the trifle may be the basis for fighting out principle in the common law, the trifle may be the basis for standing to assert principle against the public officer or the government.

Another way that a trifling interest of a taxpayer can be sufficient for standing is through the theory of the class action. A trifle multiplied by a few million becomes a large interest, and a taxpayer can bring his action on behalf of a large class of taxpayers. The Flast suit, according to the first paragraph of the complaint, was brought by seven taxpayers "on their own behalf and on behalf of all others similarly situated," 34 and their main brief effectively argued that the disbursements "will surely have a substantial effect on the aggregate bill of all the taxpayers in whose behalf this class action has been brought." 35 The Supreme Court, however, did not mention the class action, presumably because Rule 23(c)(I) requires the court to "determine by order" whether the action may be maintained as a class action and because the record contains no such order. But future taxpayer suits could be class actions under Rule 23 on behalf of millions of taxpayers.

\section{If a TRIfle Suffices for Standing, Why Not DISPENSE WITH REQUIRING ANY INTEREST?}

Federal law is clear that standing may rest upon a trifle, and it is equally clear that at least a trifling interest of the plaintiff is always required. Since the trifle makes all the difference between standing and lack of standing, the difference between a trifle and zero becomes more than a trifle! 
One may ask: Why should the law of standing be so nonsensical?

My opinion is that drawing the line between a trifle and zero is sensible, logical, and practical, as I shall try to show.

Let us begin with the common law of trespass, battery, and assault, which allows a cause of action on account of an act so trifling that the damage or injury is not discernible. The difference between A's trifling act and no act has to make all the difference between B's having a cause of action and not having one, because $B$ cannot have an action if $A$ has done nothing. The natural place to draw the line is between the trifle and nothing, and that is where the common law has drawn it.

One who did not have to pay five dollars and costs, who did not lose a fraction of a vote, who did not have to pay a $\$ 1.50$ poll tax could not have standing unless he had some other interest affected. The difference between a small hurt and no hurt is the difference between something and nothing. That is a natural place to draw the line, and that is where the federal courts have drawn it.

The alternative to requiring at least a trifling interest as the basis for standing is to allow anyone-a citizen, a person, a taxpayer, a voter, an inhabitant-to raise in court any question about the legality of governmental action which affects the public, even though the plaintiff does not allege that he is adversely affected by the governmental action he seeks to challenge. This idea, which Professor Jaffe has denominated "a public action," has been adopted by a substantial number of state courts. ${ }^{36}$ The idea is distinctly different from-but has often been confused with-the idea that a taxpayer may challenge disbursements on the theory that he has a pecuniary interest in public disbursements. ${ }^{37}$

In our present context, the most important observation that can be made about the public action is that no federal court has ever allowed it. Professor Jaffe has nevertheless conveyed the impression that the Supreme Court is tending to open the judicial doors to public actions, ${ }^{38}$ and Mr. Justice Harlan in his dissenting opinion in the Flast case adopted the Jaffe position.

Mr. Justice Harlan's entire opinion revolved around the central idea that federal courts allow the public action. For instance, he said:

36 See collection of cases in 3 K.C. Davis, Administrative Law Treatise $\$ 22.10$ (1965 Supp.).

37 The line is nevertheless hard to draw; for instance, in Vogel v. County of Los Angeles, 434 P.2d 961, 64 Cal. Rptr. 409 (1967), a taxpayer was awarded an injunction against expending public funds for administering a loyalty oath. The theory may be that the taxpayer has a financial interest, but proving that public expenditures are increased by the loyalty oath might be impossible.

38 L. Jaffe, Judicial Control of Administrative Action ch. 12, esp. 488, 499-500 (1965). 
This and other federal courts have repeatedly held that individual litigants, acting as private attorneys-general, may have standing as "representatives of the public interest." 39

He did not say, as he should have said, that an individual litigant to have standing as a private attorney-general and to represent the public interest must have an interest of his own; indeed, he went on to say that "certain of the cases may be explicable as involving a personal, if remote, economic interest," thereby implying that in some cases the plaintiff had no private interest. He cited eight cases, in each of which the plaintiff had an individual interest. ${ }^{40}$ Apparently the Harlan opinion was directly based upon Professor Jaffe's misunderstanding in the following passage:

Judge Frank in the well-known Associated Industries case believed, correctly in my opinion, that under Sanders as reinforced by Scripps-Howard it is not a necessary element of the constitutional requirement of case or controversy that the plaintiff have any interest. It is enough that the statute autho-

3988 S. Ct. at 1963.

40 Scripps-Howard Radio v. FCC, 316 U.S. 4, 15 (1942), was cited for its explanation of the Sanders case; its holding involved a stay, not standing. FCC v. Sanders Bros. Radio Station, 309 U.S. 470 (1940), was brought by a plaintiff which would lose financially by new competition. Associated Industries v. Ickes, 134 F.2d 694 (2d Cir. 1943), was brought on behalf of purchasers of coal who would have to pay more by reason of the challenged order raising minimum prices. Reade v. Ewing, 205 F.2d 630 (2d Cir. 1953), was brought by a consumer who was held "adversely affected"; the allegation was that "inclusion of any harmful ingredient" in the oleomargarine whose content was being regulated will be "detrimental to the health of a human being, will adversely affect and harm petitioner and the members of his family." Scenic Hudson Preservation Conf. v. FPC, 354 F.2d 608 (2d Cir. 1965), was brought by conservationist organizations who were held to have "a legal right to protect their special interests" in "the aesthetic, conservational, and recreational aspects of power development," and also held that the organizations had "sufficient economic interest" because their trailways would be inundated. 354 F.2d at 616. Office of Communication of United Church of Christ v. FCC, 359 F.2d 994 (D.C. Cir. 1966), involved standing before the FCC, not before the courts, and the "case or controversy" restriction was inapplicable; the holding was well expressed in one sentence:

Since the concept of standing is a practical and functional one designed to insure that only those with a genuine and legitimate interest can participate in a proceeding, we can see no reason to exclude those with such an obvious and acute concern as the listening audience.

359 F.2d at 1002. The court pointed out that a $\$ 40$ billion investment in television by American viewers is twenty times as large as the total investment of broadcasters:

Forty billion dollars would seem to afford at least one substantial brick in a foundation for standing.

Id. at 1002-03 n.17. Oklahoma v. Civil Service Commission, 330 U.S. 127 (1947), involved Oklahoma's "legal rights" to receive federal funds for highways. Marvin v. Trout, 199 U.S. 212, 225 (1905), and United States ex rel. Marcus v. Hess, 317 U.S. 537, 546 (1943), involved the statutory "right" of an informer to bring an action and keep part of what is recovered. 
rizes him to represent the public interest as a "private Attorney General."4i

Contrary to what Professor Jaffe says, Judge Frank in the Associated Industries opinion did not dispense with a requirement that the plaintiff have an interest, and he did not interpret the Sanders case as reinforced by Scripps-Howard to dispense with that requirement, for he said:

Of course, not every person is a "person aggrieved." But the Supreme Court has explicitly told us that one threatened with financial loss through increased competition resulting from a Commission's order is "aggrieved." . . . It would seem clear, then, that a consumer threatened with financial loss by a Commission's order, which fixes prices and prevents competition among those from whom the consumer purchases, is also a "person aggrieved." 42

I know of no federal case in which a plaintiff was held to have standing without asserting an interest of his own. If either Mr. Justice Harlan or Professor Jaffe knows of such a case, he fails to cite it. ${ }^{43}$

Not until late in the opinion did the fundamental error which dominates the whole Harlan opinion break into explicit statement:

This Court has previously held that individual litigants have standing to represent the public interest, despite their lack of economic or other personal interests, if Congress has appropriately authorized such suits. ${ }^{44}$

I think it entirely clear that the Court has always required "economic or other personal interests" as the basis for standing, without exception. Mr. Justice Harlan cites as "See especially" Oklahoma v. Civil Service Commission, ${ }^{45}$ in which the State of Oklahoma sought review of an order of the Civil Service Commission which the Court said "fore-

41 L. Jaffe, Judicial Control of Administrative Action 517 (1965) (footnotes omitted).

42 Associated Industries v. Ickes, 134 F.2d 694, 705 (2d Cir.), vacated as moot 320 U.S. 707 (1943).

43 The Solicitor General's brief at page 33 understood correctly what Mr. Justice Harian and Professor Jaffe misunderstood about Sanders, Scripps-Howard, and Associated Industries when it said that

in these cases Congress conferred a right to sue on a specified class of persons who had suffered a particular and ascertainable injury as a result of the challenged official action.

The "specified class of persons" in Sanders was an applicant or "any other person aggrieved or whose interests are adversely affected by any decision of the Commission granting or refusing any such application."

4488 S. Ct. at 1969.

45330 U.S. 127 (1947). 
shadowed ... that certain highway grants to Oklahoma should be withheld." 48 Oklahoma not only had an interest at stake, but the Court said it had "a legal right" to receive the funds. ${ }^{47} \mathrm{Mr}$. Justice Harlan cites as "Compare" Perkins v. Lukens Steel Co.," ${ }^{48}$ which denied standing to a steel company to get review of an order determining conditions on which the government would purchase goods. The most probable reason for the citation may be the implication that a statute can bestow "litigable rights." Of course it can. Like any other legislative body, Congress can create "rights" and one who has "rights" created by statute necessarily has standing. I can find nothing in the Lukens opinion to support the idea that parties may have standing who lack "economic or other personal interests." 49

Even though the law of standing is so cluttered and confused that almost every proposition has some exception, the federal courts have consistently adhered to one major proposition, without exception: One who has no interest of his own at stake always lacks standing.

Federal law of standing is unsatisfactory, but not because a plaintiff is always required to have an interest at stake. What the federal law of standing needs is a consistent instead of an uneven judicial practice of opening the judicial doors to a plaintiff whose interest is adversely affected, as we shall now see.

\section{Should ONE Who Is Adversely Affected Be Denied STANDing?}

The Court held in Flast that the taxpayers had standing because they had "a clear stake" as taxpayers in protecting against disbursements which violated some clauses of the Constitution. When, if ever, should one with "a clear stake" in governmental action be denied standing to challenge the legality of that action? The same question may be expressed in words that are more commonly used in judicial opinions about standing: When, if ever, should one who is adversely affected by governmental action be denied standing to challenge its legality?

46 Id. at 133.

$47 I d$, at 136.

48310 U.S. 113, 125-27 (1940).

49 Professor Jaffe's statement, at 517 , that "Congress may authorize any individual to attack an administrative order" seems to me unsupported by any decision. Congress has never authorized "any individual" to make such an attack and seems unlikely to do so. Of course, Congress, within the limits of its power to legislate, could provide that "every individual shall have a legal right" of a specified kind, and the result would then be that "every individual" would have standing to enforce the "legal right" thus created.

I think the crucial point where Professor Jaffe goes wrong is in his failure to realize that a person "adversely affected" or "aggrieved" has to have an interest of his own at stake. 
The question of "should" necessarily calls for opinion. My opinion is that the answer should be: Never.

My opinion coincides with that of Congress in numerous statutes dealing with review of determinations by specific agencies. A strong tendency is apparent in federal legislation to allow persons with interests at stake-persons who are adversely affected-to challenge governmental action. A list of federal statutes allowing standing to one who is "adversely affected" or "aggrieved" might be a rather long one.50 The same result is often accomplished by giving standing to "any person disclosing a substantial interest in such order," interest." ${ }^{52}$ Seldom are explicit provisions on standing any narrower. ${ }^{53}$ Significant is the choice of the Commissioners on Uniform State Laws, with federal experience before them, to confer standing upon "a person ... who is aggrieved by a final decision." 54

For many decades under such statutes, we have had much experience with the simple idea that anyone who is hurt by governmental action has standing to challenge it. The many statutes which in effect confer standing upon anyone who is adversely affected represent a congressional judgment in many contexts that the judicial doors should be open to those who are in fact hurt by governmental action. The statutes are numerous, and the case law under them is plentiful..$^{55}$ The consequences of opening the judicial doors to anyone who is adversely affected are readily observable and can be easily appraised: What happens is, in my opinion, that justice is enhanced in that those who are hurt in fact are not barred by lack of standing from having their cases decided on the merits. At the same time, I can find no instances of harm to the courts or to the judicial machinery from allowing those who are adversely affected to come in, for the reality remains that even when standing is accorded to anyone who is adversely affected, the courts are still in full command of the use of judicial machinery.

50 The Securities Act, for instance, provides that "any person aggrieved by an order of the Commission may obtain a review." I5 U.S.C. \& 77i(a) (1964). The Communications Act allows appeals by applicants and " $[\mathrm{b}] \mathrm{y}$ any other person who is aggrieved or whose interests are adversely affected by any order of the Commission granting or denying any application . . . " 47 U.S.C. \$ 402(b) (1964).

51 The Federal Aviation Act so provides. 49 U.S.C. \& 1486(a) (1964).

52 See, e.g., $\S 1(20)$ of the Interstate Commerce Act, 49 U.S.G. $\S 1(20)$ (1964).

53 An example of a narrower provision is that of the Federal Power Act, limiting standing to "[a]ny party to a proceeding . . . aggrieved by an order . . . ." 16 U.S.C. § $825 l(\mathrm{~b})$ (1964).

54 Revised Model State APA \& 15(a) (1961).

55 A cross-section of the case law is presented in 3 K.C. Davis, Administrative Law Treatise ch. 22 (1958 and 1965 Supp.). 
The experience we have had under the many statutes which in effect confer standing upon any person adversely affected is a sound foundation on which to build the law of standing. My opinion is that that experience should contribute to a sound interpretation of the Administrative Procedure Act's provision on standing.

Section 702 of the APA provides:

A person suffering legal wrong because of agency action, or adversely affected or aggrieved by agency action within the meaning of a relevant statute, is entitled to judicial review thereof. 50

The provision on its face is ambiguous with respect to the question whether the words "within the meaning of a relevant statute" modify only the word "aggrieved" or whether they also modify the words "adversely affected." But the ambiguity seems to be resolved by the committee reports of both Senate and House, which said:

This subsection confers a right of review upon any person adversely affected in fact by agency action or aggrieved within the meaning of any statute. ${ }^{57}$

The committee reports seem to me to be the solid part of the legislative history, ${ }^{58}$ and they seem to me to say that any person adversely affected in fact by agency action has the right of review.

The question of how the APA provision should be interpreted has never come to the Supreme Court. The closest approach to a Supreme Court interpretation is, as far as it goes, favorable to the position I have stated, but it does not go far enough. The Interstate Commerce Commission had granted a permit to a rail-owned motor carrier to act as a contract carrier, and other motor carriers sought to challenge the order. The lower court denied standing because

not only is the complaint devoid of any allegation of direct injury, present or threatened, to the motor carrier plaintiffs... but ... there was no showing of actual or anticipated direct injury such as would entitle them to institute this action. ${ }^{59}$

The Supreme Court reversed, declaring:

In the instant case, not only has the Commission created new operating rights, but they are rights in which appellants have

565 U.S.C. $\$ 702$ (Supp. II, 1967). Exceptions are stated in $\$ \S 551$ and 701.

67 SEN. Doc. No. 248, 79th Cong., 2d Sess. 212, 276 (1946).

58 See the analysis of the legislative history in 3 K.G. Davis, Administrattve Law TREATISE \& 22.02 (1958).

69 American Trucking Ass'ns v. United States, 170 F. Supp. 38, 48 (D.D.C. 1959). 
a stake. ... [A]ppellants had standing . . . under the "party in interest" criterion ... and under the "person suffering legal wrong . . . or adversely affected or aggrieved" criterion of $\S 10(a)$ of the Administrative Procedure Act . . . ${ }^{60}$

The Flast opinion, basing standing on the "stake" that a party has, instead of on "legal right" or "legal wrong," is in line with the view of the committee reports that one has standing who is adversely affected. The Supreme Court might well have taken the opportunity to interpret the APA to that effect. The question is the type which can be decided narrowly by the lower courts and then decided more broadly by the Supreme Court. The lower courts are relatively restrained, they characteristically make less intensive examinations of legislative history, and they usually make less extensive studies of experience-such as the experience under the many statutes allowing standing to persons adversely affected by the action of specific agencies. The Supreme Court, with its additional boldness and greater creativity, may respond to more profound considerations. For these reasons, I regard the problem of interpreting the APA provisions on standing largely open, since the Supreme Court has not yet clearly resolved it.

The existing law of standing in the lower federal courts, with some cases subject to "adversely affected" provisions or their equivalent, and with some cases free from any such provisions, seems quite unsatisfactory. One court, for instance, without considering the committee reports, has interpreted the APA provision to mean that anyone "adversely affected or aggrieved" has standing; on the basis of word analysis the court concluded:

It would seem reasonable in order to ascribe a meaning to every part of the subsection, to assume that the words "adversely affect or aggrieve" mean something in addition to "suffering legal wrong." 61

Another court, likewise without considering the committee reports, has held that "one who suffers economic injury as a result of agency action" has no standing unless his "legal rights" are violated.62 Although most of the case law in the lower courts interprets the APA to mean that one

60364 U.S. 1, 17-18 (1960).

61 American President Lines v. Federal Maritime Board, 112 F. Supp. 346, 349 (D.D.C. 1953). The holding was that one shipping company may challenge a grant of subsidies to its competitors. See also Mulry v. Driver, 366 F.2d 544, 547 (9th Cir. 1966), which seems, though not clearly, to say that one adversely affected by agency action has standing under the APA provision, and that the provision gives consent to sue the United States.

62 Harrison-Halsted Community Group, Inc. v. Housing \& Home Fin. Agency, 310 F.2d 99, 104 (7th Cir. 1962), cert. denied, 373 U.S. 914 (1963). 
who is adversely affected may be denied standing in absence of a showing of legal right, ${ }^{63}$ the authority of such case law is considerably weakened by the failure of each court that has so held to consider the committee reports, which in my view pull strongly away from such holdings.

Furthermore, irrespective of the APA, the line between requiring a legal right and opening the doors to one who is adversely affected is usually blurred, so that even the courts that recite that a legal right is required often allow standing to one who is adversely affected. What happens repeatedly is, in effect, that injury to the plaintiff plus illegality of the governmental action equals standing; the essence of many opinions is that injury plus illegality equals a legal right. After all, if "legal right" means an interest which is given legal protection, then a person gains a legal right whenever a court holds that he has standing. The crucial distinction thus becomes the exceedingly fine one between a previously-recognized legal right and a legal setting which causes the court to recognize for the first time the existence of a legal right; no wonder the distinction becomes blurred in practice.

An example of a holding that a person had standing because he was adversely affected even though he had no previously-recognized legal right is Gonzalez v. Freeman. ${ }^{84}$ One who had been debarred from contracting with the government was allowed to challenge the debarment. The longstanding legal tradition was that one has no "right" to contract with the government. Without mentioning the APA provision on standing, and despite the absence of a previously-recognized "right," the court decided that the debarred person had standing, on the ground that

to say that there is no "right" to government contracts does not resolve the question of justiciability. Of course there is no such right; but that cannot mean that the government can act arbitrarily .... [A]n absence of legal authority or basic fairness in the method of imposing debarment presents a justiciable con-

63 The leading case is Kansas City Power \& light Co. v. McKay, 225 F.2d 924 (D.C. Cir.), cert. denied, 350 U.S. 884 (1955). Outstanding cases include Duba v. Schuetzle, 303 F.2d 570 (8th Cir. 1962); Harrison-Halsted Community Group, Inc. v. Housing \& Home Fin. Agency, 310 F.2d 99 (7th Cir. 1962); Pennsylvania R.R. v. Dillon, 335 F.2d 292 (D.C. Cir.), cert. denied, 379 U.S. 945 (1964); Braude v. Wirtz, 350 F.2d 702 (9th Cir. 1965). None of these cases quoted or analyzed the key sentence from the committee reports. And some of the cases seem ill-considered; for instance, the last one cited held not only that employers of aliens lack standing but also that non-resident aliens lack standing to challenge a determination of their ineligibility for visas, without even considering that the word "person" in 5 U.S.C. $\$ 702$ is not limited to citizens or to residents; an opposite holding is Estrada v. Ahrens, 296 F.2d 690 (5th Cir. 1961).

64334 F.2d 570 (D.C. Cir. 1964). 
troversy in our view. The injury to appellants alleged in their complaint gives them standing to challenge the debarment processes by which such injury was imposed. ${ }^{65}$

Even though the court emphasized that the plaintiff had "no such right" to do business with the government, it held in the next sentence that the plaintiff had a right not to be unfairly deprived of what the court insisted was not a right. The court reasoned from the merits of the case-absence of authority and lack of fairness-to the conclusion that the plaintiff had standing.

Whenever a court is free to begin with the merits, it can first hold that the plaintiff is entitled to relief, and then it can return to the question of standing, which at that point answers itself because the plaintiff's entitlement to relief means that he has a legal right.

But courts which cannot decide the merits as a basis for deciding the question of standing are often compelled, in order to do justice, to hold that a person who is adversely affected has standing, even though the question of "legal wrong" or "legal right" is unresolved. An example is Overseas Media Corp. v. McNamara. ${ }^{66}$ A publisher sought to challenge the Defense Department's denial of permission to distribute through military newsstands in the Far East. Because the district court dismissed the case, and because the merits could not be decided without a hearing, the appellate court had to decide the questions of standing and reviewability without leaning on a decision about the merits. The court decided in favor of standing and reviewability. Although the court did not refer to the APA provision or use its terminology, the effect of the holding, in the terminology of the APA, was that the plaintiff was "adversely affected" and therefore had standing, even though no "legal wrong" had been shown.

Because many statutes in effect confer standing upon any person adversely affected, and because even without such statutes the courts often allow standing to any such person, the case law that would be changed by a Supreme Court holding that the APA confers standing upon any person adversely affected is rather limited. But I think that a better quality of justice would result in the limited number of cases that would be affected. An example is Harrison-Halsted Community Group, Inc. v. Housing \& Home Finance Agency. ${ }^{67}$ The plaintiffs-a community organization and 282 individuals, including 104 property owners and 144 residents of the area-sought to protect their homes and 
businesses against disruption by an urban renewal program. They alleged that residents being displaced included members of minority groups extensively discriminated against in housing and that the "loss in minority group housing is not being replaced elsewhere in the community." They further alleged that the defendant officers were violating "a series of provisions of the federal Housing Act and the regulations" and that they were depriving plaintiffs of their property without due process. ${ }^{68}$ The court refused to inquire or even to discuss the merits of the plaintiffs' contentions, holding that "plaintiffs have failed to establish any standing to sue." 69 As to the APA, the court declared:

Plaintiffs, in effect, argue that Section 10(a) [now § 702] and (c) confers standing upon any one who suffers economic injury as a result of agency action regardless of whether that person's private legal rights are violated. We do not think that this is a permissible interpretation. ${ }^{70}$

The holding seems to be that no matter what the constitutional and statutory violations, no matter how arbitrary and illegal the official action, and no matter how severe the injury to the plaintiffs, the court in the name of lack of standing refuses to consider the merits!

My opinion is that those who are adversely affected by governmental action which dislodges them from their homes and their businesses should have standing to get a judicial determination of the question whether their legal rights have been violated. The law made by the Harrison-Halsted case cannot endure. The question that invites consideration is what road to travel in getting rid of it.

One way would be by interpreting the APA provision to mean that a person adversely affected has standing, as the Senate and House committees both said. Such an interpretation would bring the federal law of standing into accord with the standing law that has been produced under the many statutes conferring standing upon those adversely affected by action of particular agencies. Although this is what I favor, alternative ways of reaching the same desirable result may also have merit.

A second way has been used by the Sixth Circuit; the result is sound, but not the method of reaching it. In Nashville I-40 Steering Committee

68 Id. at 103 .

69 Id. at 106.

$70 \mathrm{Id}$. at 104. The holding is directly contrary to that in Gart v. Cole, $263 \mathrm{~F} .2 \mathrm{~d} 244$, 250 (2d Cir.), cert. denied, 359 U.S. 978 (1959), which allowed standing to dislodged residents to challenge the Administrator's refusal to grant an oral hearing on feasibility of the relocation plan. In accord with the Harrison-Halsted holding is Johnson v. Redevelopment Agency, 317 F.2d 872 (9th Cir.), cert. denied, 375 U.S. 915 (1963). 
v. Ellington, ${ }^{71}$ the court held that persons dislodged from homes and businesses by construction of a highway have standing. The court based its conclusion on the Scenic Hudson case, ${ }^{72}$ which in turn rests on a "party ... aggrieved" provision, no counterpart of which is contained in the Federal Highway Act. Of course, if the Scenic Hudson decision were a reliable authority irrespective of statutory provisions on standing, or lack of them, as the Sixth Circuit assumed, the result would be equivalent to interpreting the APA provision to mean that persons adversely affected have standing.

A third way is more respectable and has a good deal of promise. It uses the APA clause conferring standing upon persons "aggrieved by agency action within the meaning of a relevant statute." On the question whether persons dislocated by highway construction have standing, the relevant statute is the Federal Highway Act, which says that "local

71387 F.2d 179 (6th Cir. 1967), cert. denied, 390 U.S. 921 (1968).

72 Scenic Hudson Preservation Conf. v. FPG, 354 F.2d 608 (2d Cir. 1965), cert. denied, 384 U.S, 941 (1966). The case is an important one, and the only reason for relegating it to a footnote is that it is irrelevant to my main thesis. One result of the case is that those who have an aesthetic interest in having power lines underground instead of overhead have standing to challenge an order of the FPC granting a license to construct a $\$ 162,000,000$ hydroelectric project and an order denying motions to expand administrative hearings "to include consideration of the practicality and cost of underground transmission lines, and of the feasibility of any type of fish protection device." The plaintiffs were the Conference and three towns. The Conference consisted of "a number of nonprofit, conservationist organizations." The court never said what the organizations were, except that one of the two that organized the Scenic Conference was the New YorkNew Jersey Trail Conference, some of whose trails would be inundated. On that basis, the court held that "petitioners" had "sufficient economic interest to establish their standing." Id. at 616. Apparently that included standing to object to overhead power linesl The court never stated whether the plaintiffs included fishermen or their representatives, but it held that "petitioners" had standing to protect the fish!

The opinion is filled with courageous leaps over intellectual chasms that might never be bridged; one is the interpretation of the statutory requirement that the Commission consider "other beneficial public uses, including recreational purposes" to mean "the maintenance of natural beauty, and the preservation of historic sites."

A recipe for writing such an opinion is along this line: Pour all plaintiffs together and stir, so that the identity of each will quickly be hidden, and take special care never to state the specific interests of any, except that trailways of one will be inundated; similarly, pour all issues together and stir, so that no issue except inundation of trailways can be specifically identified; say nothing about overhead power lines or protection of fish in discussing the issue of standing-postpone that discussion until after the issue of standing has been resolved; never link any particular plaintiff with any particular issue, except the one plaintiff whose trailways will be inundated; then grit the teeth and hold (at 616): "We hold that the Federal Power Act gives petitioners a legal right to protect their special interests."

A more forthright opinion would have said (1) that aesthetic interests in real life often mean economic interests and therefore may furnish the basis for standing, and (2) that fish or their representatives do not have standing unless some plaintiff shows some relation to fish. Although the opinion seems to me to invite satire, I agree with the main thrust of the holding. 
needs, to the extent practicable, suitable, and feasible, shall be given equal consideration with the needs of interstate commerce," and that a project is "to conform to the particular needs of each locality." 73 On this basis a district court has held that dislocated persons were "aggrieved" within the meaning of the Highway Act. The court declared that its decision "could be thought to involve an extension of the Scenic Hudson doctrine." "74 The Second Circuit has likewise so held with respect to persons displaced by urban renewal, who, the court said, were protected by "the relevant statute," and that

the fact that Congress intended to protect the specific interests of displacees when it enacted the section is enough to give the displacees standing, in the absence of a persuasive reason to believe that Congress intended to cut off judicial review. ${ }^{75}$

The idea that anyone whose interests are recognized by Congress may have standing under the APA is almost as desirable as the idea that the APA confers standing upon any person adversely affected. Seveneighths of a loaf is almost as good as a whole loaf.

Probably the largest category of cases that would be affected by interpreting the APA to confer standing on persons adversely affected would be the miscellaneous holdings that a competitive interest is not a basis for standing. Of the cases on this question during the past five years, perhaps about three-quarters uphold standing and only about a quarter deny standing. If the decisions are based on a rational principle explaining why a competitive interest sometimes supports standing and sometimes not, then changing the result in the quarter of the cases denying standing might be undesirable. Does the case law rest on some rational principle?

The answer is no, except to the extent that many cases do uphold standing when a statute indicates an intent to protect a competitive interest. In absence of such legislative intent, the results are largely fortuitous, as I shall try to demonstrate.

The Supreme Court has summarized the law granting or denying standing to competitors, making it appear rational:

This Court has, it is true, repeatedly held that the economic injury which results from lawful competition cannot, in and of itself, confer standing on the injured business to question the legality of any aspect of its competitor's operations. [Citations.] But competitive injury provided no basis for standing

7323 U.S.C. § 101(b) (Supp. II, 1967) and § 109(a) (1964).

74 Road Review League v. Boyd, 270 F. Supp. 650, 661 (S.D.N.Y. 1967).

75 Norwalk CORE v. Norwalk Redevelopment Agency, 395 F.2d 920, 934 (2d Cir. 1968). 
in the above cases simply because the statutory and constitutional requirements that the plaintiff sought to enforce were in no way concerned with protecting against competitive injury. In contrast, it has been the rule at least since the Chicago Junction Case, 264 U.S. 258 (1924), that when the particular statutory provision invoked does reflect a legislative purpose to protect a competitive interest, the injured competitor has standing to require compliance with that provision. ${ }^{76}$

Life and law may be less simple and less orderly. The Court's second sentence had to be limited to the cases it cited, because competitive injury does often provide a basis for standing even when the law the plaintiff seeks to enforce is in no way concerned with protecting against competitive injury. For instance, the Supreme Court has held that a broadcaster has standing to challenge the FCG's grant of a license to a competitor, despite the absence of what the Court in its third sentence called "a legislative purpose to protect a competitive interest"; ${ }^{77}$ Congress has never expressed or implied any such legislative purpose with respect to broadcasting. The reason that a broadcaster's competitive interest is a basis for standing has nothing to do with legislative purpose about protecting competitive interests; the reason is that the Communications Act provides for review by an applicant or by "any other person aggrieved or whose interests are adversely affected." That someone in enacting the review provision adverted to "a legislative purpose to protect a competitive interest" seems highly unlikely.

Similarly, because of review provisions such as "adversely affected," "aggrieved," "party in interest," and a person "disclosing a substantial interest," carriers regulated by the $\mathrm{ICG}^{78}$ carriers regulated by the $\mathrm{CAB},{ }^{79}$ gas and electric companies regulated by the $\mathrm{FPC},{ }^{80}$ and many others have standing to protect their competitive interests, even in the absence of an explicit "legislative purpose to protect a competitive interest."

But standing to protect a competitive interest is often recognized not only in absence of a legislative purpose to protect such an interest but

76 Hardin v. Kentucky Utilities Co., 390 U.S. 1, 5-6 (1968). The holding was that TVA competitors have standing because a statutory amendment had the objective of protecting their competitive interest.

77 FCC v. Sanders Bros. Radio Station, 309 U.S. 470 (1940).

78 E.g., Alton R. Co. v. United States, 315 U.S. 15, 19 (1942) (resting on the "party in interest" provision).

79 E.g., Pan American Airways Co. v. CAB, 121 F.2d 810 (2d Cir. 1941) (resting on the "substantial interest" provision).

80 Apparently the interest of the cooperatives in United States ex rel. Chapman v. FPC, 345 U.S. 153 (1953) was a competitive one, and they were held to be "aggrieved." 
also in absence of such a review provision as one conferring standing upon a person who is adversely affected. The best example may be the banking business. A judicial custom has grown up of allowing standing to a national bank, a state bank, a savings and loan association, and an investment company to challenge the grant of a charter to a competitor, the approval of a competitor's branch, or authorization to a competitor to engage in a new kind of competitive activity. ${ }^{81}$

Law which allows standing on the basis of competitive interests for banks and motor carriers and broadcasters and investment companies, and even for unions of coal miners and railroad workers with respect to a grant of a certificate of convenience and necessity to construct a pipeline, ${ }^{\text {s2 }}$ but which denies standing to public utilities whose businesses are directly hurt by TVA competition which is intended to regulate the utilities' rates, ${ }^{83}$ seems to me unexplainable by any rational principle.

Instead of holding that about three-quarters of competitive interests are a basis for standing and about one-quarter are not, I would in-

81 Except for the statutory protection of state banks from competition of national banks, I can find in the opinions no substantial reasons for the uniform decisions that various kinds of financial institutions have standing to protect their competitive interests against new banks, new branches, and new services. An early case reasoned that "if the defendant's maintenance of this branch is unlawful it is indulging in unfair competition with the plaintiff and the harm caused by the competition . . . gives the plaintiff a standing to complain," citing the Restatement of Torts. North Arlington Nat. Bank v. Kearny Fed. Sav. \& Loan Ass'n, 187 F.2d 564, 565 (3d Cir. 1951). Very common is reasoning that if the Comptroller acts illegally, the plaintiff who is hurt must have standing. For instance: Marion Nat. Bank v. Saxon, 261 F. Supp. 373, 377 (N.D. Ind. 1966). Sometimes standing results from this kind of reasoning or lack of it: "[A] competitor has an obvious interest sufficient to warrant his insistence that no branch bank be established through procedures or upon grounds not acceptable under the permissive statutes." First Nat. Bank of Smithfield v. Saxon, 352 F.2d 267, 272 (4th Cir. 1965). Another formulation: "[T] he banks surely have the standing to object to illegal competition. . . . Therefore, when a competitor believes he is being subjected to illegal competition . . . the courts should be open ... ." Webster Groves Trust Co. v. Saxon, 370 F.2d 381, 388 (8th Cir. 1966).

Of special interest is a holding that investment companies with assets of $\$ 36$ billion have standing to challenge a regulation authorizing national banks to invest funds tendered solely for investment purposes. The court's reasoning that statutory policy "to separate national commercial banking from the securities business" supports standing seems to me a non sequitur, and perhaps the court's best reason was that

a denial of standing ... would leave the plaintiffs and all others similarly situated without a right to seek redress against capricious, arbitrary and unwarranted Regulations issued by the Comptroller, however flagrant and contrary to the intent of Congress. This court, therefore, holds that the plaintiffs have standing .....

Investment Company Institute v. Camp, 274 F. Supp. 624, 637 (D.D.C. 1967).

82 National Coal Ass'n v. FPC, 191 F.2d 462 (D.C. Cir. 1951).

83 Tennessee Elec. Power Co. v. TVA, 306 U.S. 118 (1937). Cf. Alabama Power Co. v. Ickes, 302 U.S. 464 (1938). 
terpret the APA provision to mean that competitors who are adversely affected have standing. That would mean that a businessman may challenge governmental action that adversely affects his competitive interest, but it need not mean that he may challenge any governmental action that benefits a competitor. ${ }^{84}$

\section{Some Policy Thinking: An Effort to State Affirmatively What the Law of Standing Ought To BE}

The law of standing need not be either a "complicated specialty of federal jurisdiction," 85 as the Supreme Court has called it, or a mass of confused logic-chopping about bewildering technicalities. It can be much simpler and much clearer than it is. All that is necessary is to make some firm policy choices and then to apply them consistently. ${ }^{86}$

The fourteen propositions that follow are designed to show how the law of standing can be simplified and systematized, so as to minimize the confusion and to reduce the wasteful litigation about standing. Although each proposition represents my own policy choice, the main direction of the recommendations is simply toward clarity and consistency, for all fourteen propositions are now supported by some federal law, some by most such law, and some by all such law.

1. "Adversely affected" should be the basic guide. Under statutes providing for review by persons "adversely affected" or by "parties in interest," and under case law that has developed without such statutes, parties who are adversely affected now usually have standing, as I think they should. The few cases which deny standing to parties adversely affected represent the law of standing that is most in need of change. The best way to produce the change, I think, is to interpret section 702 of the Administrative Procedure Act to mean what both the Senate committee and the House committee said it meant; they said it

confers a right of review upon any person adversely affected in fact by agency action or aggrieved within the meaning of any statute. ${ }^{87}$

84 See point 7 in section VIII, below.

85 United States ex rel. Chapman v. FPC, 345 U.S. 153, 156 (1953).

86 A major reason for confusion about the law of standing is that judges tend to manipulate that law to produce substantive results they deem desirable. But those who believe that the law of standing is nothing but the product of manipulation are wrong in much greater degree than those who assume that it is nothing but the product of logical analysis. It is a mixture-about ten parts logical analysis and about one part manipulation. Unfortunately, the logical analysis often uses starting points that are the product of manipulation.

87 SEN. Doc. No. 248, 79th Cong., 2d Sess. 212, 276 (1946). See discussion of additional legislative history in 3 K.C. Davis, Administrative Law Treatise $§ 22.02$ (1958). 
My opinion is that the simple mainstay of the law of standing should be: One who is hurt in fact by governmental action has standing to challenge its legality; one who is not hurt in fact lacks standing.

Of course, interpreting the APA provision to mean that a person who is adversely affected has standing does not mean that one who is only indirectly or remotely affected necessarily has standing; lines still have to be drawn as to who is considered to be adversely affected. The Philco case, ${ }^{88}$ for instance, holding that the competitive interest of a manufacturer competing with RCA was sufficient for standing to challenge a renewal of a license of NBC, owned by RCA, probably stretches to the outer limits the "adversely affected" provision of the Communications Act.

2. A previously established legal right is not required for standing. Many holdings support this proposition, although judicial language is common that a right or a legal right is required. When a plaintiff shows that he is adversely affected by governmental action he asserts to be illegal, he should have standing, and if the court holds the action illegal, it will thereby create a legal right in the plaintiff. Even apart from the law of standing, all common law rights of plaintiffs have been created in this fashion. The pre-APA Sanders case ${ }^{89}$ is an example of a decision that a previously-recognized legal right is not required for standing; it rests on an "aggrieved or adversely affected" provision, but that element is supplied by the APA provision on standing, ${ }^{90}$ if properly interpreted.

3. A small injury should suffice. A choice has to be made as to how much adverse effect should be enough for standing. The requirement could be a large injury, a middle-sized one, or a small one. Much complexity as well as many unsatisfactory results would grow out of requiring an injury to equal litigation expense or to equal such a jurisdictional minimum as $\$ 10,000$, for the Supreme Court has properly treated as sufficient a fraction of a vote, a $\$ 1.50$ poll tax, and a fine of five dollars and costs. ${ }^{91}$ Therefore, the choice the federal courts have generally made-that an identifiable injury to an interest of the plaintiff will suffice even if the interest or the injury is a tiny one-should be firmly adopted and clarified.92

4. One who is not adversely affected should be denied standing. Some states allow a party who has no private interest at stake to bring

88 Philco Corp. v. FCC, 257 F.2d 656 (D.C. Cir. 1958), cert. denied, 358 U.S. 946 (1959).

89 FCC v. Sanders Bros. Radio Station, 309 U.S. 470 (1940).

90 5 U.S.C. § 702 (Supp. II, 1967).

91 Baker v. Carr, 369 U.S. 186 (1962) (vote); Harper v. Virginia Board of Elections, 383 U.S. 663 (1966) (poll tax); McGowan v. Maryland, 366 U.S. 420 (1961) (fine).

a2 See discussion above, in section VI. 
a suit representing the public interest. ${ }^{93}$ From the beginning, federal courts have consistently rejected this idea on the ground that one who is not adversely affected does not satisfy the requirement of a case or controversy. Although the difference between requiring a trivial interest and not requiring it is a slight one, drawing the line between nothing and something seems both natural and sound. The present uniform federal law should be continued. ${ }^{94}$

5. One who is "adversely affected" should be allowed to argue for the interest of others, including the public. To start the judicial machinery in motion, a plaintiff should be required to assert an interest of his own, but once the judicial machinery is in motion, any party should be allowed to argue for what he asserts to be desirable, including the interest of other private parties and the interest of the public. The federal courts have often taken this view, ${ }^{95}$ but much of the case law is confused and contradictory. ${ }^{96}$

6. (a) Although one cannot gain standing by asserting that another private party is adversely affected or that the public is adversely affected by the challenged action, (b) any party to a proceeding properly commenced may argue that a non-party or the public will be adversely affected by an assertedly illegal decision. Federal law here is confused because the Supreme Court has failed to take into account the necessary distinction between standing to initiate a judicial proceeding and standing to make an argument in a proceeding already properly commenced. Supreme Court law goes both ways on clause (a). ${ }^{97}$ The prac-

93 See case collection in 3 K.C. Davis, Administratrve LAW Treatise $\$ 22.10$ (1965 Supp.). Such cases should not be confused with the law of nearly all states allowing taxpayer suits to enjoin disbursements on the theory that taxpayers have a financial interest.

94 Mr. Justice Harlan in his dissenting opinion in the Flast case was mistaken in the words I am italicizing in the following passage:

This Court has previously held that individual litigants have standing to repre-

sent the public interest, despite their lack of economic or other personal interests,

if Congress has appropriately authorized such suits.

The Harlan opinion cites no case supporting the italicized words. See discussion of the Harlan citations above in section VI.

95 The leading case is FCC v. Sanders Bros. Radio Station, 309 U.S. 470 (1940). The decision rests on a provision of the Communications Act allowing standing to a person "aggrieved" or "adversely affected," but $\$ 702$ of the Administrative Procedure Act, generally applicable, supplies that element.

96 For instance, some cases hold that one who seeks to avoid new competition lacks standing, Berry v. Housing \& Home Fin. Agency, 340 F.2d 939 (2d Cir. 1965); Pennsylvania R.R. v. Dillon, 335 F.2d 292 (D.C. Cir.), cert. denied, 379 U.S. 945 (1964); Kansas City Power \& Light Co. v. McKay, 225 F.2d 924 (D.C. Cir.), cert. denied, 350 U.S. 884 (1955), but some that seem undistinguishable hold the opposite, FCC v. Sanders Bros. Radio Station, 309 U.S. 470 (1940); Bridgeport Fed. Sav. \& Loan Ass'n v. Federal Home Loan Bank Board, 307 F.2d 580 (3d Cir.), cert. denied, 371 U.S. 950 (1962); Philco Corp. v. FCC, 257 F.2d 656 (D.C. Cir. 1958), cert. denied, 358 U.S. 876 (1959).

97 E.g., Tileston v. Ullman, 318 U.S. 44 (1943) (physician lacks standing to assert con- 
tical effect of clause (a) is the same as an assertion that one who is hurt by a program but not by the asserted illegality of the program lacks standing. ${ }^{98}$ Supreme Court action supports clause (b), but the Court has not specifically articulated its position as to clause (b)..$^{99}$

7. One who has standing may challenge any kind of illegality that adversely affects him. This proposition is quite essential and seems likely to be the law of the future, even though it directly contradicts what the Court said in the Flast opinion to the effect that a taxpayer may challenge a disbursement for violation of the establishment clause but not for violation of a non-specific clause of the Constitution. The idea that one who is hurt by governmental action has standing to challenge for some kinds of illegality but not for other kinds of illegality was introduced for the first time into Supreme Court law in the Flast opinion. ${ }^{100}$ The Court, in my opinion, should not and will not maintain the idea that even one who is adversely affected by governmental action which is clearly unconstitutional may lack standing to challenge it if only a non-specific clause of the Constitution is violated. Futhermore, the Administrative Procedure Act provides that one who has

stitutional rights of patients). Contra: Pierce v. Society of Sisters, 268 U.S. 510 (1925) (school may challenge on basis of rights of parents and children). Compare Dombrowski v. Pfister, 380 U.S. 479, 486 (1965); Freedman v. Maryland, 380 U.S. 51, 56-57 (1965); United States v. Raines, 362 U.S. 17 (1960).

In Jones v. United States, 362 U.S. 257 (1960), one against whom evidence was found in searching his friend's apartment was held a "person aggrieved" with standing to challenge the legality of the search. For standing, the Court said, a person must belong "to the class for whose sake the constitutional protection is given." Id. at 261 .

98 For instance, A, a white, has a commercial interest which is adversely affected by a housing program, which is discriminatory against B, a Negro. A has no standing to challenge on the ground of the discrimination, but B has standing. After B has initiated the proceeding, $B$ may assert interests of $A$ and of the public.

99 In Barrows v. Jackson, 346 U.S. 249 (1953), whites sued a white for damages for breach of a restrictive covenant against use or occupation of land by non-Caucasians. That parties to a covenant have standing to sue for breach of the covenant is unquestionable. The Court improperly treated the problem as one of standing, but it properly held that the defendant could assert unconstitutionality on the basis of rights of unidentified non-Caucasians who were not parties. The Court again confused standing with assertion of rights of others in a proceeding already properly commenced in McGowan v. Maryland, 366 U.S. 420 (1961), where no question of standing arose because the prosecutor had standing to prosecute and the defendants had standing to defend; the only problem was whether the defendants could assert constitutional rights of others, and the Court held that they could with respect to the establishment clause of the first amendment but not with respect to the free exercise clause. See full discussion of these cases in 3 K.C. Davis, Administrative Law Treatise $\$ 22.07$ (1958 and 1965 Supp.).

100 McGowan v. Maryland, 366 U.S. 420 (1961), is not an exception to the statement made, although it may seem to be on superficial examination. "Standing" means capacity of a party to be a plaintiff, that is, to institute a judicial proceeding, and no such question arose in the McGowan case, for the only parties were the prosecutor and the criminal defendants. See full discussion in 3 K.C. Davis, Administrattve Law Treatise $\S 22.07$ (1965 Supp.). 
standing is entitled to a determination of whether the action he challenges is "contrary to constitutional right" or "in excess of statutory ... authority." 101

8. The standing of taxpayers in federal courts is and should be governed by federal law, and the federal law of standing should be the same whether the taxpayers are federal, state, or local. The Supreme Court should adhere to the principle it has adopted that standing in federal courts is governed by federal law. ${ }^{102}$ The idea advanced by the Frothingham opinion that a federal taxpayer has no standing to challenge a disbursement even though "the rule of this Court"103 allows a municipal taxpayer to challenge a disbursement is an incongruity that the Court partially terminated by the Flast decision; the Court should completely terminate it, especially since amounts exacted from federal taxpayers are now generally much greater than amounts exacted from municipal taxpayers. Federal law which would allow state or local taxpayers to have standing in circumstances in which federal law denies standing to federal taxpayers would be inherently contradictory, whether the challenge is under the establishment clause or whether it is under some clause regarded by the Court in the Flast opinion as nonspecific.

9. Any taxpayer should be deemed adversely affected financially by an illegal public disbursement. The stake of some large corporations in a federal expenditure of ten billion dollars is more than one hundred million, and even a corporation which is one per cent as large as the largest corporations has a stake of more than one million. Today's tax facts require rejection of the Frothingham idea, which may have been sound in 1923, that the effect of a federal expenditure on a federal taxpayer is "comparatively minute and indeterminable."104 Realistically, large taxpayers do have a financial stake in public disbursements, and the question has to be answered whether a line should be drawn allowing standing to large taxpayers but not to small taxpayers. For the same reason that I think the Supreme Court is right in allowing standing to one whose stake is a fraction of one vote, a $\$ 1.50$ poll tax, or a fine of five dollars and costs, I think small taxpayers should have standing. The law should presume that every taxpayer is adversely

1015 U.S.C. § 706 (Supp. II, 1967).

102 E.g., Doremus v. Board of Education, 342 U.S. 429, 434 (1952); Baker v. Carr, 369 U.S. 186, 204 (1962). When the Illinois Supreme Court found no case or controversy, the Supreme Court rendered a clear-cut decision that federal law determines whether a case or controversy is present under the Constitution, and the Court held that it was. In re Summers, 325 U.S. 561 (1945).

103 Frothingham v. Mellon, 262 U.S. 447, 486 (1923).

$104 \mathrm{Id}$. at 487 . 
affected by an illegal public expenditure; such a presumption is already the law of the federal courts to some extent, ${ }^{105}$ so that the recommendation is merely that existing law be strengthened.

10. Although a taxpayer should have standing to challenge disbursements for any illegality without exception, standing is not the only legal barrier to successful challenge, and the law of unreviewability, the law of forms of proceedings, and substantive law may all be fashioned to produce justice and efficiency concerning taxpayer suits. The Court said in the Flast opinion that a taxpayer has standing to challenge only "exercises of congressional power under the taxing and spending clause" and not expenditures "in the administration of an essentially regulatory program." 106 The distinction seems unsatisfactory because the government probably uses its spending power whenever it spends, even if the disbursement is also supported by some other granted power. Furthermore, many activities are neither primarily spending nor primarily regulatory-the Vietnam war, for instance. Perhaps a better system than what the Court proposed would be standing law which permits a taxpayer to challenge any expenditure for any kind of illegality, coupled with other law which would restrict and channel taxpayer suits in whatever way is found desirable. A cardinal idea is that the single purpose of standing law is to require proper plaintiffs, and that other purposes may be better accomplished through other law. The long period since the Frothingham case cut off suits by federal taxpayers to challenge disbursements leaves the substantive law, the law of unreviewability, and the law of forms of proceedings inadequately developed with respect to the questions that can be raised in taxpayer suits, the kinds of disbursements that are reviewable, and the classes of illegality that are appropriate for judicial inquiry. Law can be fashioned that will not only follow the principles developed for other purposes since 1923 but may break new ground. For example, the legality of grants but not the legality of payments for goods and services might be judicially reviewable, and the Court of Claims, the Tax Court, Boards of Contract Appeals, and the Renegotiation Board might be the exclusive tribunals to determine disputes as to whether payments by the government are inadequate or excessive. The substan-

105 The Third Circuit said of an expenditure by the Virgin Islands that "the alleged minuteness of the amount of the present taxpayers' interests may not be urged as a ground for denying them to sue." Smith v. Government of Virgin Islands, 329 F.2d 131, 134 (3d Cir. 1964). The Court quoted from the Supreme Court of the Territory of Hawaii: "It is not necessary that the plaintiff should show actual damage to himself .... [D]amage is presumed to result to all taxpayers." Lucas v. American Hawaii Eng'r \& Constr. Co., 16 Hawaii 80, 86 (1904).

10688 S. Ct. at 1954. 
tive law, as well as the machinery to administer it, can be molded in any desired direction. I would expect that constitutional problems about scope of federal power under the tenth amendment would quickly disappear, for the Supreme Court would firmly hold that Congress has a full power to tax and spend for the general welfare. Law of standing which for three decades prevented an authoritative determination of the constitutionality of the TVA seems to me to indicate an illness of the basic constitutional system; substantive law that the TVA is of course constitutional can be a sign of restored health.

11. The figment about floods of litigation if taxpayer suits are allowed is demonstrably false. Nearly all states allow taxpayers to challenge disbursements, ${ }^{107}$ and anyone who cares to look at the facts can readily find that taxpayer suits are few, not numerous. Supreme Court law from 1899 to 1923 allowed federal taxpayers to challenge federal disbursements, with no resulting flood of litigation; ${ }^{108}$ for instance, in 1907 the Supreme Court decided on the merits a taxpayer suit to enjoin the Secretary of the Treasury from making payments for building the Panama Canal. ${ }^{109}$ In 1920 the Supreme Court reversed a state court's denial of an injunction sought by a state taxpayer against the expenditure of state funds to print ballots for a referendum, but no multiplicity of vexatious taxpayers' suits resulted.110 Opening the judicial doors to taxpayers' suits does not cause floods; it hardly causes trickles.

12. Another palpably false claim that deserves summary rejection is the assertion that allowing taxpayer suits will mean government 'by judges. One assertion is:

The vice in the proposal to have "taxpayers' suits," it seems to me, lies in the idea that ultimate power in our country should reside with the courts.... The sorts of questions which arise with respect to the spending power are, in my view, better adapted for consideration and decision by the executive and legislative branches of the Government than by the judiciary. ${ }^{111}$

107 Apparently only one state denies standing to a municipal taxpayer to challenge a municipal expenditure. Asendorf v. Common School Dist., 175 Kan. 601, 266 P.2d 309 (1954). iNew York appears to be the only state having clear law denying standing to a state taxpayer to challenge a state expenditure. St. Clair v. Yonkers Raceway, Inc., 13 N.Y.2d 72, 192 N.E.2d 15, 242 N.Y.S.2d 43 (1963), cert. denied, 375 U.S. 970 (1964).

108 In Bradfield v. Roberts, 175 U.S. 291 (1899), a federal taxpayer sued the Treasurer of the United States to enjoin a payment to a hospital of the District of Columbia, and the Court decided on the merits. Federal reports thereafter reflect few taxpayer suits.

109 Wilson v. Shaw, 204 U.S. 24 (1907).

110 Hawke v. Smith, 253 U.S. 221 (1920).

111 Dean Erwin N. Griswold, in 89th Cong., 2d Sess., Senate, Judiciary Comm., Subcomm. on Constitutional Rights, Judicial Review, Hearings on S. 2097, at 496 (1966). 
Another assertion is that allowing taxpayers' suits will involve the courts

in the sort of detailed and immediate supervision and review of legislative and executive actions which is wholly unsuited to judicial action. ${ }^{112}$

These assertions are answerable at a very elementary level. Federal courts have fully-developed bodies of law that limit judges to issues appropriate for judicial determination. Judges do not undertake tasks that are "wholly unsuited" to them. Any challenge of governmental action in a taxpayer's suit is likely to be governed by section 706 of the Administrative Procedure Act ${ }^{113}$ on scope of review, but the limitations of section 706 are almost always followed even when that provision does not apply; the judicial function is normally limited to preventing arbitrary exercise of discretion, action not in accordance with law, violation of constitutional rights, action in excess of statutory authority, departures from required procedure, and findings unsupported by substantial evidence.

13. The law of standing is unsuited to assuring that issues will be appropriate for judicial determination and properly presented. The purpose of the law of standing is to protect against improper plaintiffs. Courts which try to use the law of standing to accomplish other purposes seldom succeed and usually cause confusion. Courts should limit themselves to issues appropriate for judicial determination, but not through the law of standing; that needs to be done by further emphasis on the concept of "issues appropriate for judicial determination" in the law of ripeness, sovereign immunity, political questions, and unreviewability. Courts should not try to use the law of standing to assure that plaintiffs will be responsible or that the issues they raise will be responsibly raised. The Court went wrong in the Flast opinion when it tried to use the law of standing to assure

that the questions will be framed with the necessary specificity, that the issues will be contested with the necessary adverseness and that the litigation will be pursued with the necessary vigor .... ${ }^{114}$

The law of standing can assure some element of "adverseness" but it cannot assure either specificity or vigor; a party with a precious interest at stake may frame questions without "the necessary specificity" and may pursue the litigation without "the necessary vigor." Other

112 Brief filed in Flast case by Solicitor General Erwin N. Griswold and his four colleagues, at 44.

1135 U.S.C. \& 706 (Supp. II, 1967).

11488 S. Ct. at 1955. 
law, such as the law of the Rescue Army case, ${ }^{115}$ needs to be developed to assure competent presentation of cases. Courts should avoid issues that are unreal, hypothetical, or remote, but not through the law of standing; that is the proper province of other law, including the law of ripeness.

14. In the broad perspective of an entire system of government, the American way of using courts to enforce constitutional and statutory limitations on the authority of officers is as appropriate when the statute under which the officers act has been enacted pursuant to the congressional power to tax and spend as it is when the statute has been enacted pursuant to some other congressional power. The power to disburse government money often means power over lives, businesses, property, and activities. Possibly more than half of all activities of the federal government rest on the spending power. No one planned and no one would plan the system into which we drifted in 1923 through a quirk in the law of standing, under which we have relied on courts to answer all constitutional questions except questions about the spending power, and under which courts have checked the legality of officers' action except when they are acting pursuant to the spending power. If the legality of officers' action should be checked by courts, the check is as fitting when they act under the spending power as when they act under any other power.

The Supreme Court in the Flast case has taken the first step toward the needed correction, by holding that a taxpayer has standing to challenge a disbursement under a specific clause of the Constitution. The Court should, I think, take the second step of so holding with respect to all constitutional and statutory limitations on the authority of officers.

115 Rescue Army v. Municipal Court, 331 U.S. 549 (1947). See also Public Affairs Associates, Inc. v. Rickover, 369 U.S. 111 (1962). 